\title{
15
}

\section{Lessons for Iraq and Afghanistan}

\section{Carter Malkasian and Daniel Marston}

Robert $\mathrm{O}^{\prime}$ Neill did not take part in the Iraq or Afghan wars. Yet he has had an abiding influence over how the United States and the West have approached the past 15 years of war. His experiences, books (Vietnam Task and General Giap), and most importantly, his teaching guided a cadre of scholar-practitioners involved in the Iraq and Afghan wars. His teachings lay at the root of many of the reforms that took place. Without him, the United States and the West would have been far less able to meet the challenges of the recent wars. Through six decades, $\mathrm{O}^{\prime} \mathrm{Neill}$ has been a father of strategic thinking on insurgency, carefully teaching and guiding from behind.

We met Professor O'Neill in the late 1990s as young graduate students coming to Oxford to work under his supervision. We were two of his last students. By that time, he had served in Vietnam, taught at The Australian National University, run the International Institute for Strategic Studies (IISS), and taken the Chair of the Chichele Professor of War at Oxford. As Americans, we had been exposed to Vietnam in our earlier studies, but our first true instruction in insurgency and counter-insurgency came from Professor $\mathrm{O}^{\prime}$ Neill. With that in mind, this chapter will trace the development of his thinking and chart his influence on strategy in Iraq and Afghanistan. 


\section{Vietnam}

O'Neill's deployment to Vietnam as an infantry officer from 1966 to 1967 forms the starting point of his thinking on insurgency. He was there for a year with the 5th Battalion, Royal Australian Regiment (5RAR). O'Neill chronicled the deployment in Vietnam Task, published shortly after the battalion returned to Australia. As noted in Tony White's chapter, $\mathrm{O}^{\prime}$ Neill wrote most of the book while on active duty in Vietnam; his account documents his attempt to steer an objective path through a campaign in which he was deeply involved. Vietnam Task was never intended to be definitive. O'Neill wrote it intending that it would serve as a record of a moment in the war, in one part of the campaign and in one unit's experience of which he was part.

Vietnam Task has had a significant impact on our thinking and research, during work on our degrees and beyond. ${ }^{1}$ In the late 1990s, the Vietnam War was still a divisive topic for many in the United States. Having grown up in the shadow of the war, we had heard the often contentious discussions taking place in families and neighbourhoods, as well as in academe. We have read and re-read Vietnam Task and learned different things from it each time, as the context of our own experiences working in Iraq and Afghanistan have developed, as well as when we have carried out our own research into the Vietnam War.

Vietnam Task is an important addition to the larger body of work on Vietnam and has stood the test of time, not only as a personal memoir, but as a study of insurgency, counter-insurgency, and adaptation. $\mathrm{O}^{\prime}$ Neill laid out several key concepts in Vietnam Task, especially regarding analysis and the need for constant learning and adaptation in the midst of war. ${ }^{2}$ There is one particular chapter that we consider timeless, Chapter 13 'A re-evaluation of strategy', which has helped shape our thinking on numerous issues over the past two decades.

\section{Context}

A key theme of Chapter 13 is the need to understand context. In his discussion of the main effort of a campaign, $\mathrm{O}^{\prime}$ Neill stressed that:

$1 \quad$ O'Neill, Robert J. (1968) Vietnam Task, Melbourne: Cassell.

2 Ibid. 
the most fundamental question seemed to be the determination of our aim. Was it to kill Viet Cong [VC], to bring the main force to battle, to isolate the main force from the people, to assist in civil reconstruction, to restore Government control to villages or to cut VC supply lines? As strategy can be most effectively applied only with knowledge of the opponent's aim, it was important to consider exactly what the VC were attempting to do in order to achieve a victory. ${ }^{3}$

He then described how, in Vietnam, the allied coalition had to contend with an enemy that could field guerrilla forces as well as main forces, and how ' $[\mathrm{VC}]$ main force regiments ... [w] $\mathrm{w}$ ere not to win the support of the people, but to throw back the forces of the Government and by a process of continued expansion and amalgamation to inflict final crushing defeat on the Government Army'. ${ }^{4}$

In making these points, $\mathrm{O}^{\prime} \mathrm{Neill}$ articulates the complexity of the war in Vietnam and the need for a multilayered approach to the campaign: 'the most direct means of winning the war lies in eliminating the Viet Cong cadres from the villages, positive Government action to administer the population cannot be put into effect until the main force Viet Cong regiments in a particular locality have been neutralised and are kept from interfering with the restoration of Government control.'5 (We will come back to this last important point.) This could be construed to align with the mantra repeated for much of the Iraq and Afghanistan campaigns: 'clear, hold, build'. We would agree, but only to a point; $\mathrm{O}^{\prime}$ Neill is always clear that issues in Vietnam are specific to that time, place, and campaign, and care is necessary in applying lessons from one campaign to another.

\section{Adaptation}

Adaptation and creative thinking is another major theme of Chapter 13 in Vietnam Task. In presenting this theme, O'Neill placed it within the context of his battalion's culture of debate, declaring that '[Lt Colonel John Warr, commanding officer] had been stimulating discussion of our methods ever since the battalion had been raised and scarcely a week passed in which he did not ask me what our aim 
in Phuoc Tuy was and then debate the matter ${ }^{6}{ }^{6}$ Halfway through the tour, Lt Colonel Warr asked $\mathrm{O}^{\prime} \mathrm{Neill}$ to write a paper outlining the aims of the campaign, then used it to frame a debate among all the platoon and company commanders in the battalion.

That paper also served as a framework for how the battalion could succeed. In his 2006 address to the IISS, O'Neill recounted how he crafted five points to guide the strategy of his battalion over the second half of their deployment:

1. Our principal challenge was not the Viet Cong main force and the North Vietnamese Army but the political cadres which the Viet Cong had inserted into towns and villages.

2. Our prime task had to be the removal of enemy political cadres from the towns and villages.

3. Our second priority was to help with reconstruction and development so that the local people's needs would be met effectively and they might come to feel that a non-communist government would give them a better chance of a good life than a communist one.

4. Major offensive operations in or near populated areas were highly counter-productive in terms of winning popular support.

5. Other kinds of operations, especially those aimed at eliminating Viet Cong cadres and winning popular support, were much less costly to ourselves in casualties and therefore much more sustainable politically by our own and allied governments.

Within these five points lie concerns about overly conventional operations, unpopular governments, and avoiding harm to civilians that we would both later hear in $\mathrm{O}^{\prime}$ Neill's lectures at Oxford.

In later years, O'Neill argued that the American public stopped supporting the war in Vietnam from 1968 onward because too little had been achieved at too great a cost. In his view, the five points above offered ways to conduct operations and achieve successes at a reasonable cost. ${ }^{7}$ In sum, $\mathrm{O}^{\prime}$ Neill left Vietnam with a strong

6 Ibid., p. 182.

7 O'Neill, Robert (2006) 'World Order and the War on Terror: Prospects and Perspectives', lecture at International Institute for Strategic Studies, 29 November. 
appreciation for context (especially its political and social aspects), adaptation, and a set of five operational guidelines that might have helped get to a happier outcome.

After Vietnam and the publication of Vietnam Task, O'Neill wrote a book on the North Vietnamese military leader, Vo Nguyen Giap, and won a teaching position at The Australian National University. ${ }^{8}$ He next turned his focus to the Korean War, but he continued to refine his thinking on Vietnam and insurgency.

\section{Oxford}

In 1987, O'Neill became the Chichele Professor of War at All Souls College, Oxford University. A major theme in his lectures and seminars was the difficulty of handling insurgencies and their prominence in modern warfare. What cannot be overstated is that in the 1990s O'Neill was one of the few professors in history, political science, or strategic studies teaching about insurgency. Indeed, before September 2001, it was not uncommon to hear top scholars dismiss the idea that the United States would ever face an insurgency again. This was the era of the revolution in military affairs and 'shock and awe'. Too many generals, policy-makers, and scholars lived in the afterglow of the impressive US success in the 1991 Gulf War. In contrast, $\mathrm{O}^{\prime}$ Neill believed that, because great powers find it too expensive and counterproductive to fight each other, insurgency and terrorism had become the dominant form of warfare. With foresight, he argued that insurgency and terrorism were at the cutting edge of international politics and would not go away for decades. Therefore, students needed to understand insurgency and be thoroughly familiar with the most important recent historical examples.

Wary of generalisation, $\mathrm{O}^{\prime}$ Neill used historical cases to ground his thoughts. In his class on the history of modern war, Malaya and Vietnam were the subject of multiple lectures. For the Americans studying under $\mathrm{O}^{\prime}$ Neill, Malaya was a largely unknown conflict. Vietnam, of course, was not. $\mathrm{O}^{\prime}$ Neill was always clear that issues in Vietnam are specific to their time and place, and that care is necessary in applying lessons from one campaign to another. Context is everything: war is 
ever-changing and the experiences of the various forces would change based upon which province and which year they served in Vietnam. War is grey and always will be; there are no hard and fast rules. ${ }^{9}$

That said, at Oxford, O'Neill did not shy away from sharing his insights and thinking with his students. In line with his own prior experiences, $\mathrm{O}^{\prime} \mathrm{Neill}$ discussed the virtues of light tactics in counterinsurgency: patrolling, gathering intelligence, and working with the people. For Vietnam, he lauded the Marine Corps' combined action platoons that embedded into local forces and lived with them in the village. ${ }^{10}$ In contrast, he strongly criticised the conventionally minded US search and destroy operations, and the use of mechanised vehicles in Vietnam. From his point of view, it was tough to substitute for the light infantryman. (While at Oxford, O'Neill was also Honorary Colonel of the 5th Battalion, Royal Green Jackets, a descendant of the 60th Royal American Regiment, one of the first light infantry units in the British Army; designed specially to fight in another irregular war - the French and Indian War, 1754-1763.) And he was deeply critical of heavy-handed behaviour on the part of Western troops. For him, indiscriminate use of firepower - as demonstrated in the My Lai massacre, the killings of the Phoenix program, and other tragic events - oppressed the local people and turned them against the government. Publics would not accept such behaviour, especially in the media age.

With 30 years of contemplation behind him, O'Neill did not merely talk about tactics. On the controversial question of whether the United States could have won the Vietnam War, he was pessimistic. In his assessment, the best chance would have been for the South Vietnamese government (with US support) to have adopted better counter-insurgency tactics pre-1965, before the main force war. Doing so might have given politicians the breathing space to support a long war. Nevertheless, for $\mathrm{O}^{\prime}$ Neill, the key factor was the South Vietnamese Government. It would have had to improve its policies and solidify for success to have been possible. Overlooking the possibility that the South Vietnamese Government was illegitimate in the eyes of the common

9 Discussion between Daniel Marston and Robert O'Neill, 2005.

10 See Hennessey, Michael (1997) Strategy in Vietnam: The Marines and Revolutionary Warfare in I Corps, Westport, CT: Praeger. 
people was one of the fundamental flaws of the Vietnam campaign. ${ }^{11}$ In correspondence with Carter, O'Neill explained: 'Westmoreland's plan of mid-1965 ignored the domestic political struggle in Vietnam. It would not have mattered how effective his military operations were if the South Vietnamese Government continued to be ineffective in addressing the state of popular welfare, and failed to compete more strongly with the Communists in this area.'12

Above all, in his teachings at Oxford, O'Neill offered a strategic viewpoint on insurgency and counter-insurgency that has strongly influenced us and his other students, specifically three larger points that had not appeared in Vietnam Task. They are harshly realistic and sober.

First, successful counter-insurgency may demand a long commitment and possibly also a large number of troops.

Second, such a commitment must be politically sustainable, which means that early successes are essential. The foreign forces 'must be able to win at an acceptable cost in a reasonable amount of time', he said in a 2000 lecture. 'Lives of the intervening forces and time are the two most precious commodities. ${ }^{13} \mathrm{~A}$ democratic politician may not be able to gather the necessary support if under political fire over setbacks or atrocities in the field. For this reason, a military insufficiently sensitive to the local population can torpedo the whole effort.

Third, the host government needs political cohesion. A government that is too divided or broken by sectarianism, feuds, or cycles of revenge is unlikely to defeat an insurgency, no matter how many troops are poured in. He told his students: 'wars for other people's futures require their support. Security of all states rests ultimately on their own shoulders. ${ }^{14}$ Ultimately, even if the interventionist power could clear enough space to permit a host nation to attempt to restore governance, the host nation still needs to decide how this government should look - and govern. The interventionist can provide support in terms of advisors, but must accept the possibility that the solution may not look anything like our own governance structures in the

11 Discussion between Daniel Marston and Robert O'Neill, 2005.

12 Correspondence between Robert O'Neill and Carter Malkasian, 26 May 2003.

13 O'Neill, Robert (2000) lecture on 'Vietnam, 1968-1975', Oxford University, 4 March.

14 Ibid. 
West. We cannot make a host nation into little America or Britain, yet we must remember and maintain the idea that without a cohesive government, counter-insurgency is likely to fail. ${ }^{15}$ This strategic realism would later define his assessment of the chances for success in Iraq and Afghanistan.

Beyond his lectures, O'Neill pressured his graduate students to understand the dynamics of insurgencies and how to address them. He directed graduate students writing on general strategy or land war in the twentieth century to be familiar with relevant history in insurgency and counter-insurgency. John Hillen, a US Army officer, wrote a dissertation on peacekeeping and the United Nations that captured O'Neill's cautious guidance, that intervention is often long and difficult, but is also an unavoidable feature of the international system. Carter's dissertation on wars of attrition contained material on counter-insurgency and Vietnam because $\mathrm{O}^{\prime} \mathrm{Neill}$ felt he needed to compare attrition and counter-insurgency. Dan's dissertation on the Indian Army in the Burma campaign focused on how fostering a culture of learning and adaptation is a key aspect of both developing professionalism within the military and improving performance in combat.

O'Neill's most important student in this field was John Nagl, a US Army officer who was convinced that the United States would face more insurgencies than conventional wars in its future. Nagl first came to Oxford in 1988 as a master's student. He returned in 1995 to earn his doctorate under $\mathrm{O}^{\prime}$ Neill's tutelage ${ }^{16}$ His dissertation compared the British effort in Malaya to the United States' effort in Vietnam. His argument strongly mirrored $\mathrm{O}^{\prime}$ Neill's own emphasis on adaptation. Nagl found that organisational culture had prevented the United States from adopting good counter-insurgency tactics. The dissertation was eventually published as Learning to Eat Soup with a Knife, ${ }^{17}$ one of the most widely read books on counter-insurgency. O'Neill was pleased, both with the dissertation and with Nagl's courage in questioning the doctrines of the army in which he was a serving officer. As graduate

\footnotetext{
15 Discussion between Daniel Marston and Robert O'Neill, 2005.

16 Nagl, John (2014) Knife Fights: A Memoir of Modern War in Theory and Practice, New York: Penguin, pp. 38-9.

17 Nagl, John (2005) Learning to Eat Soup with a Knife: Counterinsurgency Lessons from Malaya and Vietnam, Chicago: Chicago University Press.
} 
students, we were assigned Nagl's dissertation right off O'Neill's All Souls office shelf, long before the published version ever hit the bookstores.

\section{Iraq and Afghanistan}

When 11 September 2001 struck, O'Neill was completing his tenure at Oxford, soon to move back to Australia. As the wars in Afghanistan and Iraq unfolded, O'Neill's own thoughts were characteristically sober. He advocated good counter-insurgency tactics, but was circumspect about how much could actually be achieved.

\section{Students at War}

O'Neill found his students heavily involved in the war effort. John Hillen became Assistant Secretary of State for Political-Military Affairs. Dan started teaching at Sandhurst, made repeated trips to Iraq and Afghanistan, and later took a chair at the US Army Command and Staff College. He brought $\mathrm{O}^{\prime}$ Neill's emphasis on learning and adaptation into the strategic discussions in which he was involved with British and American commanders in the UK, the US, Iraq, and Afghanistan. Carter spent 18 months as a civilian advisor to the Marines in $\mathrm{Al}$ Anbar province, and then nearly four years in Afghanistan, two in a district of Helmand and another two as the political advisor to the top US commander, General Joseph Dunford. Nagl was perhaps the most involved of all. He served as the operations officer of a battalion in Iraq and then became one of the leading and most well-known reformers calling for a new, better approach.

At a time when most US officers and policy-makers found themselves ill-prepared to deal with the problem of insurgency, $\mathrm{O}^{\prime} \mathrm{Neill's}$ students were ready to make recommendations from a solid academic grounding. He had given them a framework to examine the problem. He continued to be a mentor and sounding board for us as we worked to address various tactical, operational, and strategic aspects of the wars.

Unlike Vietnam, the US military instituted a dramatic attempt to adapt itself to fight an insurgency in Iraq and Afghanistan. Within the military, General David Petraeus, General James Mattis, Dr David 
Kilcullen, and John Nagl spearheaded the creation of a new counterinsurgency doctrine and its implementation. Nagl's Learning to Eat Soup with a Knife was standard fare for officers. The reform effort culminated in the publication of the Counterinsurgency Field Manual, for which Nagl wrote the introduction. O'Neill's influence can be seen in the introduction's emphasis on knowledge of history, the length and difficulty of counter-insurgency campaigns, the limited utility of massed operational manoeuvre and heavy firepower, and the dominance of insurgency in modern warfare. The passage 'most enemies either do not try to defeat the United States with conventional operations or do not limit themselves to purely military means' especially echoes $\mathrm{O}^{\prime}$ Neill's views. ${ }^{18}$

The counter-insurgency manual eventually came under heavy criticism for two things. First, critics on the right claimed the manual deemphasised killing and had soldiers and marines concern themselves too much with building relations with local population. Second, critics on the left claimed that the manual was overly optimistic about the ability of a heavy, lengthy, and expensive troop commitment to defeat an insurgency. O'Neill never directly weighed in on these debates, but we can guess at his thoughts. He would have outright rejected the first criticism. For him, building relationships lessens resistance and gives democratic politicians political space to support a war effort. For the second criticism, he would have been partly sympathetic about the dangers of over-optimism, especially given his own emphasis on the precedence of politics and a cohesive government. Yet he would not have backed away from a long and possibly substantial commitment as a necessary condition for success. In O'Neill's opinion, if a democratic state wants to defeat an insurgency, it may have to confront that burden.

O'Neill's other students have also contributed to US and allied strategy. Now Assistant Secretary of State for Political-Military Affairs within the US Department of State, John Hillen worked to coordinate guidelines for counter-insurgency across the entire US Government.

18 (2007) The U.S. Army/Marine Corps Counterinsurgency Field Manual, Chicago: Chicago University Press, pp. li-liv. 
He shared $\mathrm{O}^{\prime}$ Neill's idea that dealing with insurgent and terrorist adversaries is as much political as military, and that therefore diplomats and development experts had to be involved. ${ }^{19}$

On the more academic side of things, in 2008 we put together Counterinsurgency in Modern Warfare, an edited collection of case studies of the major counter-insurgency campaigns. Though far less influential than the counter-insurgency manual, it followed O'Neill's model of using historical cases to inform understanding. We asked a range of academics and practitioners to write specific chapters to provide a variety of perspectives, and avoided listing any specific lessons for people to walk away with. We hewed closely to $\mathrm{O}^{\prime} \mathrm{Neill's} \mathrm{thoughts} \mathrm{on}$ the key role of context and how it inhibits drawing out specific lessons for future campaigns. ${ }^{20} \mathrm{We}$ considered that the proper role of the book was to act as a catalyst for debate and discussion; it would be left to the reader to draw their own conclusions. Consequently, the book has no conclusion and foreswears any general theory - for which we were sometimes criticised in reviews. A few points in the introduction show O'Neill's influence, particularly where it highlights the dangers of overly militarised strategies and the role of politics and society, stating 'tactical brilliance at counter-insurgency translates into very little when political and social context is ignored or misinterpreted' ${ }^{21}$ As usual, $\mathrm{O}^{\prime}$ Neill was involved in developing the book; he read several chapters and provided important critical feedback.

Carter later wrote War Comes to Garmser. Published in 2013, the book is a 30-year history of conflict in one district of war-torn Helmand province. The book's commentary on the need to build relationships with local leaders and do no harm owes something to $\mathrm{O}^{\prime} \mathrm{Neill's}$ teachings a decade before. Carter and $\mathrm{O}^{\prime}$ Neill corresponded heavily during the book's revision process, especially about how local dynamics can shape the course of a conflict as much as foreign intervention, which is a theme of the book. In correspondence, O'Neill noted: 'Armies come,

19 Hodge, Nathan (2011) Armed Humanitarians: The Rise of the Nation Builders, New York: Bloomsbury Publishing, pp. 155-60.

20 Malkasian, Carter and Daniel Marston (eds) (2008) Counterinsurgency in Modern Warfare, Oxford: Osprey Publishing.

21 Ibid., p. 16. 
armies go, but the people of Afghanistan continue to move along their own path through the history of the region in which they live. What more can one say?'22

\section{Wisdom}

Throughout the Iraq and Afghan wars, O'Neill developed his own assessment of the situation, which he delivered in lectures and talks on Iraq and Afghanistan. He kept his eye firmly on the overall strategic situation. When Dan sent in reports from his various trips, highlighting the reform and apparent progress that he was witnessing on the battlefields, O'Neill would always ask the same question: 'To what end?' He had been right to ask. At times, all of us students had been guilty of losing sight of the bigger picture, focusing on tactical progress and assuming larger strategic problems could be fixed later.

On Iraq, O'Neill always doubted the odds of success. He never bought into the idea of a short, quick war. Unlike many other experts, including ourselves, $\mathrm{O}^{\prime} \mathrm{Neill}$ expected an insurgency to break out after the 2003 US invasion. Though no fan of the invasion, he believed the United States and its allies needed to be ready to face an insurgency. ${ }^{23}$

As the Iraqi insurgency gained speed, $\mathrm{O}^{\prime} \mathrm{Neill}$ criticised US tactics as overly conventional. In 2006, he told IISS: 'Although some US and allied soldiers have by now developed good ideas on what to do to win the support of the civilian population, the Coalition lacks the strength to put them into effect. ${ }^{24}$

For $\mathrm{O}^{\prime}$ Neill, the central problem in Iraq was not tactics, but the absence of a government that could control the country. He thought it would be impossible to build one: 'I cannot see the Iraqi government retaining the political cohesion and authority which is necessary for an army to function well in counter insurgency ... [T] he only way to keep the country together is by dictatorial rule and massive occasional applications of force. ${ }^{25}$ On the face of it, O'Neill appears overly

22 Correspondence between Robert O'Neill and Carter Malkasian, 17 February 2012.

23 O'Neill, Robert (2006) 'World Order and the War on Terror: Prospects and Perspectives', lecture at International Institute for Strategic Studies, 29 November.

24 Ibid.

25 Correspondence between Robert O'Neill and Carter Malkasian, 13 December 2006. 
pessimistic, given that within a year the surge would win dramatic successes. Over the longer term, he appears prescient. He wrote to Carter in early 2004:

The insurgency in Iraq is much more complex than that in Vietnam, and much more difficult to handle. I shall be very surprised if, a few years after the US pulls out of Iraq, there is a stable, democratic government there. The society is just too divided — so many factions, so many different loyalties, so much history, so little trust, so much vengeance to be taken - both on rival factions and on the US. ${ }^{26}$

This, it seems, is exactly what has come to pass. The United States indeed was not interested in a protracted commitment, and in June 2014 the Iraqi Government suffered a devastating defeat at the hands of the Islamic State, the progeny of the original Iraqi insurgents.

$\mathrm{O}^{\prime}$ Neill was similarly pessimistic about Afghanistan. Although he supported the US and allied commitment, he found Afghanistan to be just as complex as Iraq: 'the whole country is deeply marked by very complex historical experience - the waves of migration, the proximity of India, the Durand line, the Pashtun problem, and the five or six wars that the region was been through in the past thirty odd years ... these are peculiarly difficult people for intervention forces to control and work with. ${ }^{27}$ Even more than Iraq, $\mathrm{O}^{\prime}$ Neill doubted that his critical component of counter-insurgency - a cohesive government - could be built. He wrote to Carter in 2012:

The final outcome ... will depend on the leadership capacities of the men in Kabul ... Of course there is a deeper question here: can foreigners ever hope to implant a government in Afghanistan and then watch it take root successfully? We have an awful lot of history which says that the answer to this question is No. There is too much history of foreign attempts at domination, local resistance of many kinds and at many levels, offered with such perseverance so that it was ultimately successful. ${ }^{28}$ 
Because of the stakes, O'Neill never called for abandoning Afghanistan. He also never thought that the West could solve the country's problems. There was almost a sense of inevitability in his view of the West's intervention and then defeat, a tragedy bound to play itself out.

For O'Neill, Iraq and Afghanistan epitomised the difficulties and tragedies of facing insurgencies - wars that cannot be wished away. Often, in his opinion, the United States and its allies would have to get involved. In 2015, he advised that, strategically, there are two choices:

[E]ither stay out or (and preferably in my view) intervene very judiciously, building support for the local good guys, not undercutting them. It takes years, but so be it ... The US armed forces are not going to be able to avoid this kind of intervention - but I stress the word 'judiciously'. And here is the mission for the new generation of leading military thinkers and practitioners. ${ }^{29}$

\section{Conclusion}

We have tried to trace an evolution in Professor O'Neill's thoughts from Vietnam to the present. As a young officer in Vietnam, his experiences gave him a framework for what he believed counter-insurgency should look like on the ground. His experiences highlighted for him the dangers of certain approaches, especially mistreating the people, or using too much firepower. As a professor, tactics gave way to strategy. A long commitment, early successes, and a cohesive government were necessary conditions for success, if a Western democracy chose to intervene. By the time of Iraq and Afghanistan, this final point - placed within the surrounding political and cultural context became a critical factor in his thinking. Throughout, he asserted that insurgency is now the dominant form of war and, in spite of its difficulties, cannot always be avoided.

Today, counter-insurgency has fallen into ill repute because of America's difficulties in Iraq and Afghanistan. After 2011, US policy-makers deemed its successes too small to be worth the cost. Meanwhile, new counter-terrorist tactics that offer a different way to 
fight have gained credence, and the United States has tried to work through partners in order to avoid a substantial deployment of troops. These methods may succeed. If so, a substantial troop deployment may be less important than $\mathrm{O}^{\prime}$ Neill believed. Nevertheless, these new approaches are only under consideration because $\mathrm{O}^{\prime} \mathrm{Neill's}$ points on a long commitment, a cohesive government, and the inevitability of insurgency have proven all too true.

Ultimately, more than a decade into both the Afghanistan and Iraq campaigns, we must acknowledge that we have not put these points into practice to the extent required. As a Western coalition we can rightly claim that we have undertaken tactical reform, and grown to understand the changing character of the war, but we have not truly integrated these points, especially regarding a cohesive government, sufficiently to articulate and seek a realistic end state that would constitute a true victory for the host nation.

For us, Professor $\mathrm{O}^{\prime} \mathrm{Neill}$ is a realistic and far-thinking scholar who shaped the modern understanding of insurgency and counterinsurgency through teaching and mentoring. He put in place a cadre of scholar-practitioners with a solid grounding in insurgency. He forced his students to learn about insurgency and counter-insurgency during more peaceful times, when their study was too often deemed unnecessary. We would have lacked the wisdom to study them on our own. Whatever successes we have had over this past 15 years of small wars begin with his teachings. 
This text is taken from War, Strategy and History: Essays in Honour of Professor Robert O'Neill, edited by Daniel Marston and Tamara Leahy, published 2016 by ANU Press, The Australian National University,

Canberra, Australia. 